\title{
Sodium selectivity of semicircular canal duct epithelial cells
}

\author{
Muneharu Yamazaki ${ }^{1,2}$, Tao Wu', Satyanarayana R Pondugula', Donald G Harbidge ${ }^{1}$ and Daniel C Marcus ${ }^{1 *}$
}

\begin{abstract}
Background: Sodium absorption by semicircular canal duct (SCCD) epithelial cells is thought to contribute to the homeostasis of the volume of vestibular endolymph. It was previously shown that the epithelial cells could absorb $\mathrm{Na}^{+}$under control of a glucocorticoid hormone (dexamethasone) and the absorptive transepithelial current was blocked by amiloride. The most commonly-observed target of amiloride is the epithelial sodium channel (ENaC), comprised of the three subunits $\alpha-, \beta$ - and $\gamma$-ENaC. However, other cation channels have also been observed to be sensitive in a similar concentration range. The aim of this study was to determine whether SCCD epithelial cells absorb only $\mathrm{Na}^{+}$or also $\mathrm{K}^{+}$through an amiloride-sensitive pathway. Parasensory $\mathrm{K}^{+}$absorption could contribute to regulation of the transduction current through hair cells, as found to occur via vestibular transitional cells [S. H. Kim and D. C. Marcus. Regulation of sodium transport in the inner ear. Hear.Res. doi:10.1016/j.heares.2011.05.003, 2011].

Results: We determined the molecular and functional expression of candidate cation channels with gene array (GEO GSE6197), whole-cell patch clamp and transepithelial recordings in primary cultures of rat SCCD. $\alpha-, \beta-$ and $\gamma-\mathrm{ENaC}$ were all previously reported as present. The selectivity of the amiloride-sensitive transepithelial and cell membrane currents was observed in Ussing chamber and whole-cell patch clamp recordings. The cell membrane currents were carried by $\mathrm{Na}^{+}$but not $\mathrm{K}^{+}$, but the $\mathrm{Na}^{+}$selectivity disappeared when the cells were cultured on impermeable supports. Transepithelial currents across SCCD were also carried exclusively by $\mathrm{Na}^{+}$.

Conclusions: These results are consistent with the amiloride-sensitive absorptive flux of SCCD mediated by a highly $\mathrm{Na}^{+}$-selective channel, likely $\alpha \beta \gamma$-ENaC. These epithelial cells therefore absorb only $\mathrm{Na}^{+}$via the amiloridesensitive pathway and do not provide a parasensory $\mathrm{K}^{+}$efflux from the canals via this pathway. The results further provide caution to the culture of epithelial cells on impermeable surfaces.
\end{abstract}

\section{Background}

Hearing and balance depend on the ion homeostasis of the luminal fluid, endolymph $[1,2]$. Transduction of stimulus into neuronal signals is mediated and regulated predominantly by $\mathrm{K}^{+}$and $\mathrm{Ca}^{2+}$; however, maintenance of a very low $\left[\mathrm{Na}^{+}\right]$is also critical to prevent a toxic overload of the sensory hair cells (e.g.,[3]) and for osmotic balance. Cellular $\mathrm{Na}^{+}$absorptive mechanisms have been observed in the cochlea and vestibular labyrinth [4]. The primary $\mathrm{Na}^{+}$transport pathways are mediated by an amiloride- and benzamil-sensitive ion channel and by a nonselective cation channel. The former is found in Reissner's membrane, saccule and semicircular canal

\footnotetext{
* Correspondence: marcus@ksu.edu

${ }^{1}$ Cellular Biophysics Laboratory, Department of Anatomy \& Physiology,

Kansas State University, Manhattan, KS 66506, USA

Full list of author information is available at the end of the article
}

duct (SCCD). The most commonly-observed target of these drugs is the epithelial sodium channel $(\mathrm{ENaC})$, comprised of the three subunits $\alpha-, \beta$ - and $\gamma$-ENaC.

The cation selectivity of the amiloride- and benzamilsensitive ion channel is of interest since 1) nonselective and poorly-selective cation channels have also been observed to be sensitive in a similar concentration range of amiloride and benzamil (see Discussion) and 2) the high concentration of endolymphatic $\mathrm{K}^{+}$would lead to an important efflux of $\mathrm{K}^{+}$through these cells. The high $\mathrm{Na}^{+}$selectivity of epithelial cells in Reissner's membrane was recently reported [5]; in the present study we also found a high sodium selectivity of epithelial cells of the SCCD. The potential influence of the permeability of the culture support on ion channel expression was also investigated and found to have a profound effect.
C Biomed Central

C 2011 Marcus et al; licensee BioMed Central Ltd. This is an open access article distributed under the terms of the Creative Commons Attribution License (http://creativecommons.org/licenses/by/2.0), which permits unrestricted use, distribution, and reproduction in any medium, provided the original work is properly cited. 


\section{Results}

SCCD epithelial cells grown on permeable supports Transepithelial absorption of $\mathrm{Na}^{+}$and $\mathrm{K}^{+}$(Ussing chamber recordings)

Transepithelial cation absorption was measured as the short-circuit current $\left(\mathrm{I}_{\mathrm{sc}}\right)$ across the epithelium from the apical side towards the basolateral side under conditions where the only major permeant ions on the apical side were either $\mathrm{Na}^{+}$or $\mathrm{K}^{+}$(Figure 1 ). In $\mathrm{Na}^{+}$-rich solution on the apical side, amiloride $(100 \mu \mathrm{M})$ significantly inhibited the $I_{\mathrm{sc}}$ by $84 \%$ (Table 1 ) when the cells were

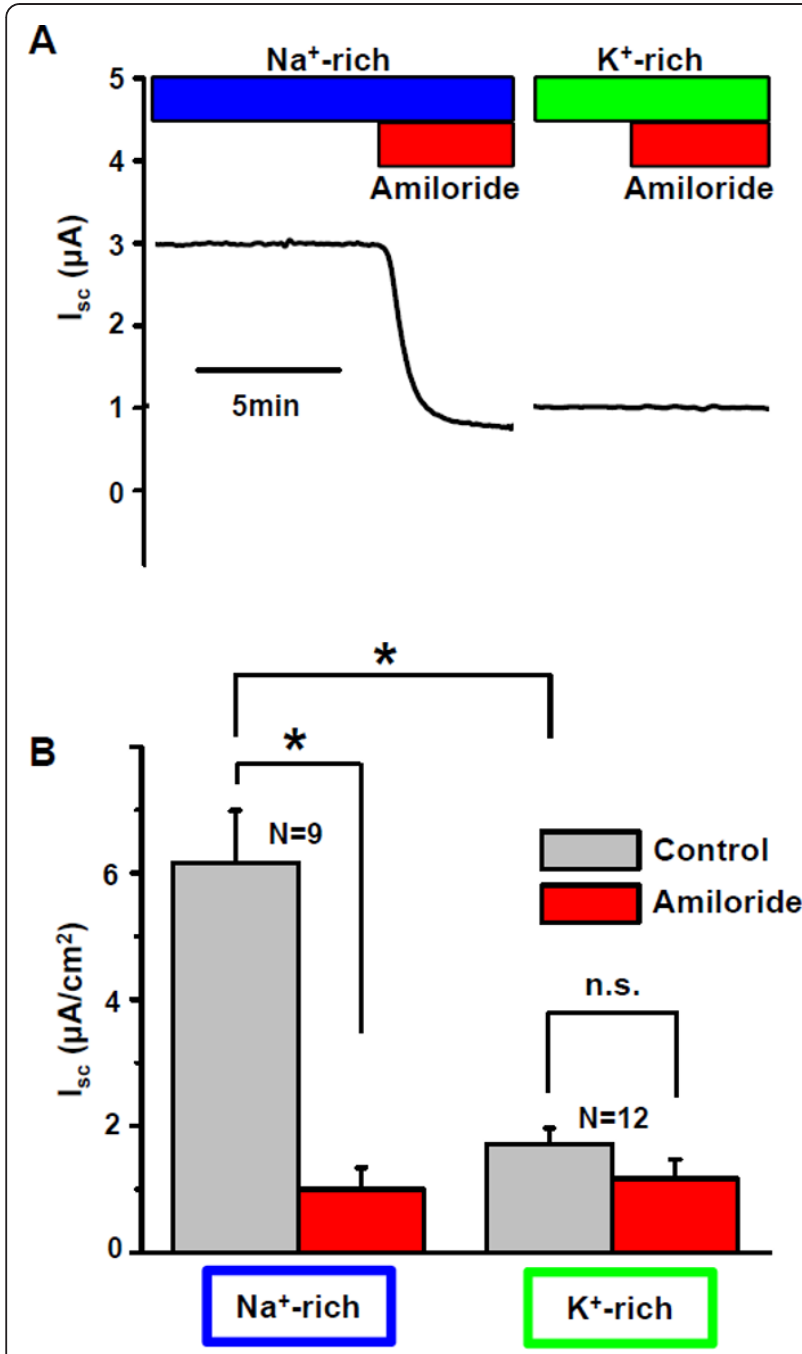

Figure 1 Short circuit current $\left(\mathrm{I}_{\mathrm{sc}}\right)$ across primary cultures of semicircular canal duct (SCCD) epithelial cells grown on permeable supports. A) Representative traces. Basolateral solution was physiological saline and apical solution was either $\mathrm{Na}^{+}$-rich (left) or $\mathrm{K}^{+}$-rich (right). Note break in time axis; Isc of each culture insert was measured in each apical solution using different order of exposure and washing in between measurements. Amiloride (100 $\mu \mathrm{M})$ added on the apical side as indicated by horizontal red bar. B) Summary of normalized currents from experiments as in A. grown on permeable supports. $\mathrm{I}_{\mathrm{sc}}$ in $\mathrm{K}^{+}$-rich solution in the absence of amiloride was significantly smaller than in $\mathrm{Na}^{+}$-rich solution (Figure $1 \mathrm{~B}$ ). In $\mathrm{K}^{+}$-rich solution on the apical side, amiloride had no significant effect on the $\mathrm{I}_{\mathrm{sc}}$ (Figure 1B, Table 1). A representative experiment is shown in Figure 1A and a summary of similar experiments is shown in Figure $1 \mathrm{~B}$. In $\mathrm{K}^{+}$-rich solution, $\mathrm{I}_{\mathrm{sc}}$ was under $1 \mu \mathrm{A} / \mathrm{cm}^{2}$ in 11 experiments, but in one experiment was $3.16 \mu \mathrm{A} / \mathrm{cm}^{2}$. The single sample with the large current was likely due to a culture support with fewer perforations (lower permeability) than usual. Cellular cation currents (whole-cell patch clamp recordings) The currents were measured under conditions where the only major permeant ions were either $\mathrm{Na}^{+}$or $\mathrm{K}^{+}$; $\mathrm{Cl}^{-}$was replaced by gluconate. (Figures $2,3 \mathrm{~A}, 4$ ). In $\mathrm{Na}$ ${ }^{+}$-rich bath solution, amiloride $(100 \mu \mathrm{M})$ significantly inhibited the inward whole-cell current (carried mostly by bath $\mathrm{Na}^{+}$at $-120 \mathrm{mV}$ ) by $59.6 \%$ (Table 1 ). A representative experiment is shown in Figure 2 and 2a summary of similar experiments is shown in Figure 3A and 4. The reversal voltage in the absence of amiloride reflects the asymmetrical $\left[\mathrm{Na}^{+}\right]$and the leftward shift of the reversal voltage in the presence of amiloride is consistent with the block of a $\mathrm{Na}^{+}$-permeable channel. These whole-cell data are consistent with the observations of $\mathrm{Na}^{+}$-selective $\mathrm{I}_{\mathrm{sc}}$ (above). In $\mathrm{K}^{+}$-rich bath solutions, the current at $-120 \mathrm{mV}$ was significantly smaller than in $\mathrm{Na}^{+}$(Figure 4). Amiloride $(100 \mu \mathrm{M})$ had no significant effect on the reversal voltage nor on the inward whole-cell current (carried mostly by bath $\mathrm{K}^{+}$at -120 $\mathrm{mV}$ ) (Table 1). A representative experiment is shown in Figure 2 and a summary of similar experiments is shown in Figure $3 \mathrm{~A}$ and 4.

\section{SCCD epithelial cells grown on impermeable supports} Cellular cation currents (whole-cell patch clamp recordings) When primary SCCD cells were grown on impermeable supports (glass coverslips) and were bathed in $\mathrm{Na}^{+}$-rich solution, amiloride $(100 \mu \mathrm{M})$ had no significant effect on the inward whole-cell current (carried mostly by bath $\mathrm{Na}^{+}$at $-120 \mathrm{mV}$; Figure 3B, Table 1). In $\mathrm{K}^{+}$-rich bath solution, amiloride $(100 \mu \mathrm{M})$ led to a small inhibition of the inward whole-cell current (carried mostly by bath $\mathrm{K}^{+}$at $-120 \mathrm{mV}$ ) by $8.1 \%$ (Table 1 ). There was no significant difference in the amiloride-sensitive inward current between the $\mathrm{Na}^{+}$- rich bath at $-120 \mathrm{mV}\left(\mathrm{I}_{-120}=\right.$ $-9.7 \pm 4.6 \mathrm{pA} / \mathrm{pF}, \mathrm{n}=6$ ) and $\mathrm{K}^{+}$-rich bath solutions ( $\mathrm{I}_{\text {- }}$ $120=-5.6 \pm 1.2 \mathrm{pA} / \mathrm{pF}, \mathrm{n}=7$ ) (Figure $3 \mathrm{~B}$ ). It was observed that culture on impermeable supports led to no significant change in $\mathrm{Na}^{+}$-current, but to a marked increase in the K-current (factor of 18) (Figure 3, Table 1 ). These results are consistent with the expression of amiloride-insensitive, nonselective cation channels (see Discussion). 
Table 1 SCCD transepithelial and cellular currents

\begin{tabular}{|c|c|c|c|c|c|}
\hline & & \multicolumn{2}{|c|}{$\mathrm{Na}^{+}$-rich } & \multicolumn{2}{|c|}{$\mathrm{K}^{+}$-rich } \\
\hline & & control & amiloride & control & amiloride \\
\hline \multirow[t]{2}{*}{ permeable } & $\begin{array}{c}\text { Ussing chamber } \\
\left(I_{s c}, \mu A / \mathrm{cm}^{2}\right)\end{array}$ & $6.16 \pm 0.83(9)$ & $1.00 \pm 0.34(9)^{*}$ & $1.71 \pm 0.26(12)$ & $1.17 \pm 0.3(12) \mathrm{ns}$ \\
\hline & $\begin{array}{l}\text { Whole cell patch } \\
\left(\mathrm{I}_{-120 \mathrm{mv}}, \mathrm{pA} / \mathrm{pF}\right)\end{array}$ & $-60.8 \pm 20.3(9)$ & $-36.3 \pm 17.3(9)^{*}$ & $-3.8 \pm 0.1(5)$ & $-3.6 \pm 0.3(5) \mathrm{ns}$ \\
\hline $\begin{array}{c}\text { impermeable } \\
\left(\mathrm{I}_{-120 \mathrm{mv}}, \mathrm{pA} / \mathrm{pF}\right)\end{array}$ & Whole cell patch & $-137.6 \pm 68.7(6)$ & $-127.9 \pm 64.2(6) \mathrm{ns}$ & $-69.6 \pm 6.1(7)$ & $-64.0 \pm 5.7(7)^{*}$ \\
\hline
\end{tabular}

Table entries are means \pm SEM (number of experiments).

$\mathrm{I}_{\mathrm{sc}}$ : short circuit current $\left(\mu \mathrm{A} / \mathrm{cm}^{2}\right), \mathrm{I}_{-120 \mathrm{mv}}$ : whole-cell patch clamp current at $-120 \mathrm{mV}$ command voltage $(\mathrm{pA} / \mathrm{pF})$

Amilorde concentration was $100 \mu \mathrm{M}$ for all experiments.

Significant differences: ${ }^{*}, \mathrm{P}<0.05 ; \mathrm{ns}$, not significant.

Comparisons: Values in amiloride vs control (without amiloride) using the paired t-test.
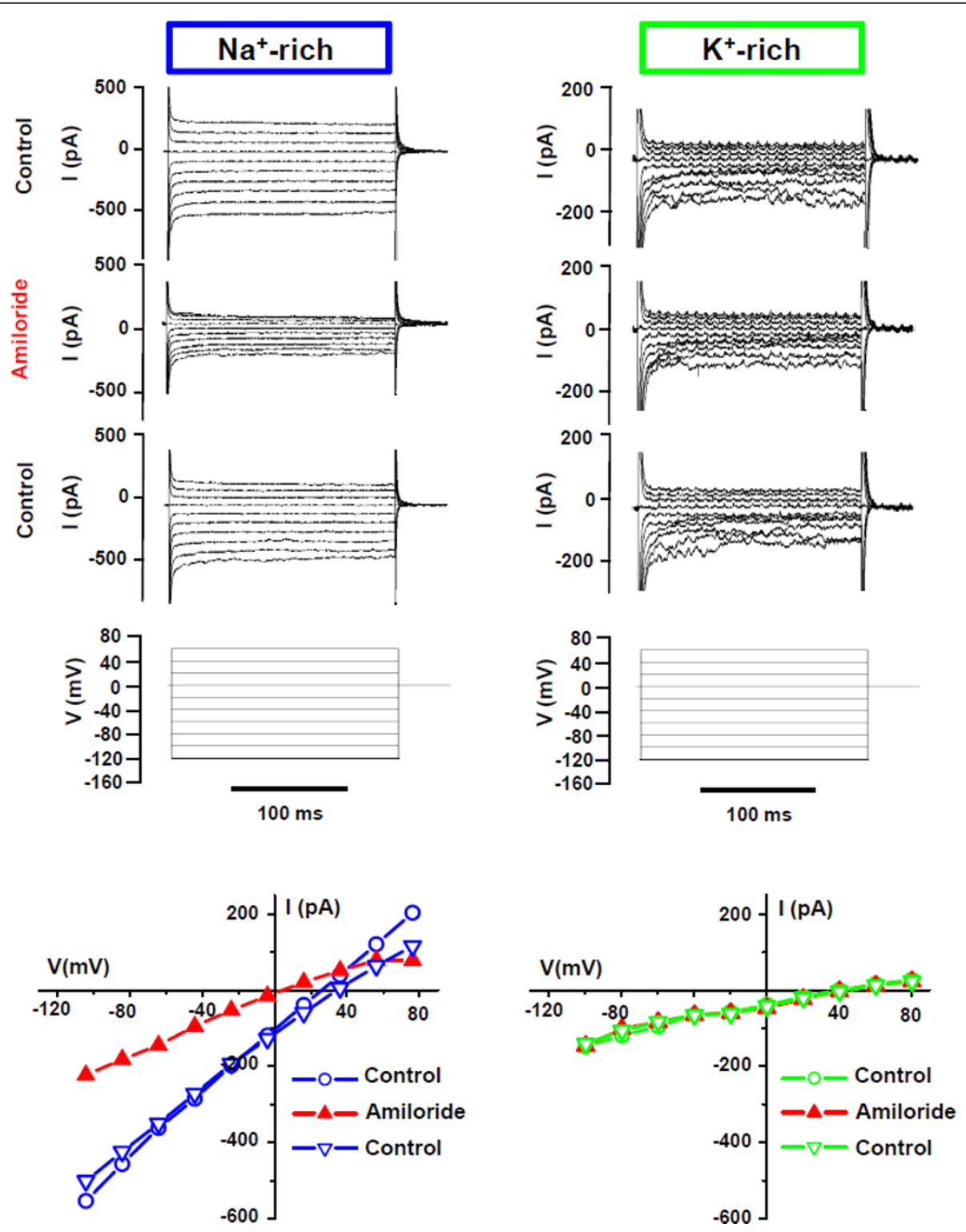

Figure 2 Representative whole-cell patch clamp recordings and current-voltage curves from SCCD epithelial cells grown on permeable supports. Left panel, $\mathrm{Na}^{+}$-rich bath and pipette, Right panel, $\mathrm{K}^{+}$-rich bath and pipette. The holding potential and voltage command protocol are illustrated. Amiloride concentration was $100 \mu \mathrm{M}$. Bottom: Representative current-voltage relationships of the whole cell currents in the presence and absence of amiloride $(100 \mu \mathrm{M})$. Voltages are corrected for the liquid junction potentials (see Methods). 


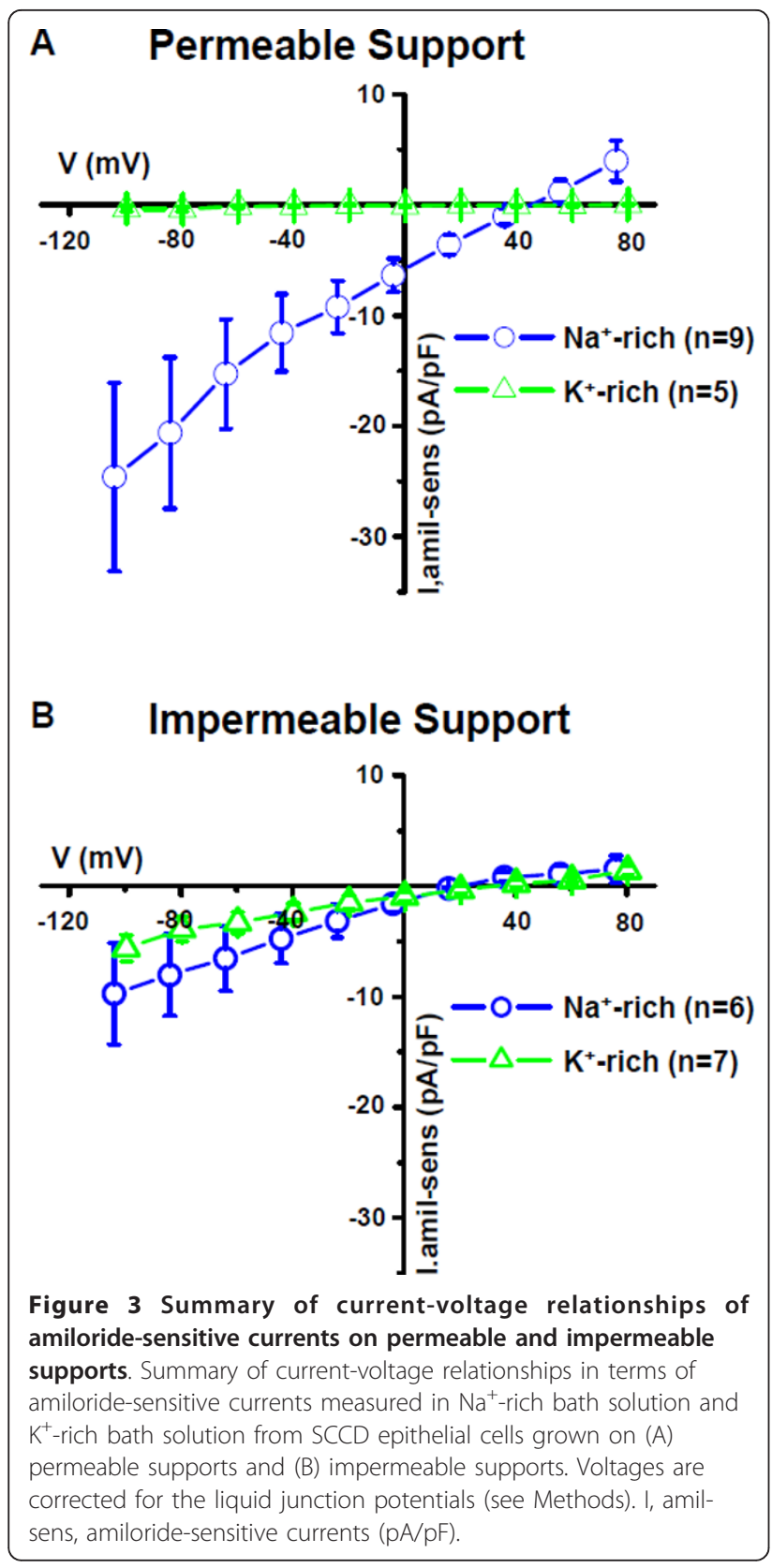

Expression of amiloride-sensitive cation channels in SCCD We utilized gene array (GEO GSE6197; Table 2) [6,7] to partially address the question of the participation of amiloride-sensitive nonselective cation channels. Several isoforms of acid-sensitive ion channels (ASIC) and cyclicnucleotide gated (CNG) channels were listed in our gene array of rat SCCD. We examined whether each gene was present or absent in primary cultures of SCCD after incubation for $24 \mathrm{~h}$ with $100 \mathrm{nM}$ dexamethasone. ASIC1a, 2a were listed; ASIC1a had a call of "Present", but ASIC2a was "Absent" (Table 2). CNGA1, 2, 3 were listed in the gene array and CNGA1 yielded a call of "Present", but CNGA2, 3 each received a call of "Absent". HCN1, 2, 3, 4

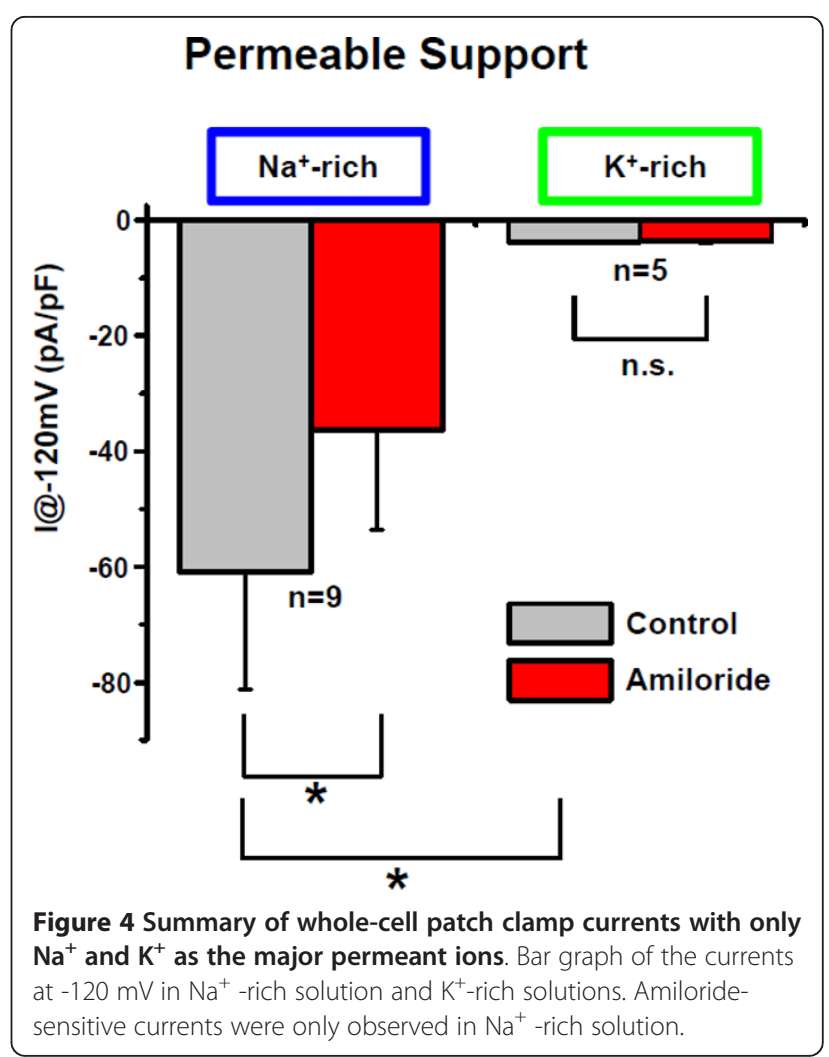

were listed; HCN1, 3 had a call of "Present", but HCN 2, 4 were both "Absent" (Table 2). ENaC can be an nonselective cation channel under some subunit combinations (see Discussion) and the $\alpha-, \beta$ - and $\gamma$-ENaC subunits were all expressed in SCCD cultured on permeable supports, as determined by gene array, RT-PCR and sequence validation [6-8] (Table 2).

\section{Discussion}

Several epithelial domains in the inner ear have been shown to absorb $\mathrm{Na}^{+}$either by itself or with $\mathrm{K}^{+}$from the lumen [4]. Highly-selective amiloride-sensitive $\mathrm{Na}^{+}$ absorption has been shown in Reissner's membrane of the cochlea, while parasensory $\mathrm{K}^{+}$efflux was found in the outer sulcus epithelial cells of the cochlea and in the vestibular transitional cells. The present study is the first demonstration that the SCCD epithelial cells provide a highly-selective amiloride-sensitive $\mathrm{Na}^{+}$absorption pathway in the vestibular labyrinth that does not provide a route for parasensory $\mathrm{K}^{+}$efflux.

The $\left[\mathrm{Na}^{+}\right]$of vestibular endolymph is normally only about $10 \mathrm{mM}$, but rises rapidly during ischemic anoxia [9]. Local ischemic events occur in response to inflammation and other insults that release TNF-alpha (infection, autoimmune disorders, etc) [10]. Increased endolymphatic $\left[\mathrm{Na}^{+}\right]$can lead to cytosolic overload in hair cells [3] and vestibular dysfunction. Local release of TNF-alpha in 
Table 2 Amiloride sensitive channels

\begin{tabular}{|c|c|c|c|c|c|c|}
\hline name & gene bank & gene & $\begin{array}{c}\text { amiloride, } \mathrm{IC}_{50}, \\
\mu \mathrm{M}\end{array}$ & $\begin{array}{c}\text { cation selectivity, } \\
\mathrm{P}_{\mathrm{Na}} / \mathrm{P}_{\mathrm{K}}\end{array}$ & $\begin{array}{c}\text { gene array*, DEX (GEO, } \\
\text { GSE6197) }\end{array}$ & reference \\
\hline$\alpha-\mathrm{ENaC}$ & NM_031548 & Scnn1a & 0.17 & 1 & $P$ & {$[15,14,20,21]$} \\
\hline$\alpha \beta-\mathrm{ENaC}$ & U35174 & Scnn1b & 4 & $\geq 100$ & $P$ & {$[18,19]$} \\
\hline$\alpha \gamma-\mathrm{ENaC}$ & U37539 & Scnn1g & 0.13 & $\geq 100$ & $P$ & {$[18,19]$} \\
\hline $\begin{array}{l}\alpha \beta \gamma^{-} \\
\mathrm{ENaC}\end{array}$ & & & 0.1 & $\geq 100$ & $P$ & {$[16,18,14]$} \\
\hline ASIC2a & Y14635 & Accn 1 & 28 & $\geq 10$ & A & {$[18,31]$} \\
\hline ASIC1a & NM_024154 & Accn2 & 10 & $6-13$ & $P$ & {$[18,31,32]$} \\
\hline CNGA1 & NM_012923 & Cong1 & $(100 \text { tested })^{* *}$ & 1 & $P$ & {$[23-25,27]$} \\
\hline CNGA2 & AF_126808 & Cncg4 & ND & 1 & A & {$[24,25,27,26]$} \\
\hline CNGA3 & AJ272429 & Cnga3 & ND & 1 & A & {$[24,25,27,26]$} \\
\hline HCN1 & NM_053375 & Hen1 & ND & 0.3 & $P$ & {$[28,29,35]$} \\
\hline HCN2 & Al112487, AW532988 & $\mathrm{Hen} 2$ & ND & 0.3 & A & {$[28,29,35]$} \\
\hline HCN3 & NM_053685 & Hen3 & ND & 0.3 & $P$ & {$[28,29,35]$} \\
\hline $\mathrm{HCN} 4$ & AF247453 & $\mathrm{Hen} 4$ & ND & 0.3 & A & {$[28,29,35]$} \\
\hline TRPV1 & $\begin{array}{c}\text { AB015231, AF158248, } \\
\text { AB041029 }\end{array}$ & Trpv1 & Insens & NSC & A & {$[36,37]$} \\
\hline TRPV2 & NM_017207 & Vrl1 & ND & NSC & A & {$[36]$} \\
\hline TRPV4 & NM_023970 & Trpv4 & ND & NSC & A & [36] \\
\hline TRPV6 & NM_053686 & Trpv6 & ND & NSC & $A$ & {$[36]$} \\
\hline
\end{tabular}

* gene was detected as present $(P)$ or absent $(A)$ in the presence of $100 \mathrm{nM}$ dexamethasone.

** CNGA1 channels were not inhibited by $100 \mu \mathrm{M}$ amiloride.

Insens, insensitive; ND, not determined; NSC, non-selective cation channels.

the inner ear may have the additional exacerbating effect of reducing ENaC-mediated $\mathrm{Na}^{+}$absorption [11]. Dexamethasone may therefore have multiple mitigating effects by not only stimulating $\mathrm{ENaC}$ expression and activity, as shown previously $[8,12]$, but also by releasing the inhibition from TNF-alpha $[11,13]$. These results point to a potential therapeutic utility of dexamethasone to correct elevated $\mathrm{Na}^{+}$levels in vestibular disorders associated with TNF-alpha-mediated inflammation.

Generally, $\mathrm{ENaC}$ is known as a highly $\mathrm{Na}^{+}$-selective channel with a $\mathrm{Na}^{+}$to $\mathrm{K}^{+}$permeability of $>80$, but there are reports of $\mathrm{ENaC}$ being poorly- or non-selective to cations under some conditions and this can be due to either altered $\mathrm{ENaC}$ subunit stoichiometry or increased expression of unrelated nonselective cation channels (Table 2) [14].

ENaC subunit stoichiometry and amiloride sensitivity. The $\alpha$-, $\beta$ - and $\gamma$-ENaC subunits were all expressed in SCCD epithelial cells at the mRNA and protein levels, although the stoichiometric subunit association in the apical membrane is not known. Homomeric $\alpha$-ENaC channels behave as nonselective cation channels $[14,15]$. On the other hand, heteromeric $\alpha \beta \gamma$-ENaC is highly $\mathrm{Na}$ ${ }^{+}$-selective under some subunit combinations $[14,16,17]$. Heteromeric $\alpha \beta-\mathrm{ENaC}$ and $\alpha \gamma-\mathrm{ENaC}$ are also highly $\mathrm{Na}$ ${ }^{+}$-selective [18,19] (Table 2).

The $\mathrm{Na}^{+}$current in SCCD is likely carried by heteromeric $\alpha \beta \gamma-\mathrm{ENaC}$ or $\alpha \gamma-\mathrm{ENaC}$ but not homomeric
$\alpha-\mathrm{ENaC}$ or $\alpha \beta-\mathrm{ENaC}$, as judged by ion selectivity and amiloride sensitivity. Homomeric and heteromeric $\mathrm{ENaC}$ are pharmacologically defined through their inhibition by amiloride and its analogs [20]. The $\mathrm{IC}_{50}$ value for amiloride (Table 2) of homomeric $\alpha$-ENaC channels is $0.17 \mu \mathrm{M}$ [21], heteromeric $\alpha \beta \gamma-\mathrm{ENaC}$ is $0.1 \mu \mathrm{M}$ [16], $\alpha \beta$ - $\mathrm{ENaC}$ is $4 \mu \mathrm{M}, \alpha \gamma-\mathrm{ENaC}$ is $0.13 \mu \mathrm{M}$ [19]. The $\mathrm{IC}_{50}$ value of $\mathrm{I}_{\mathrm{sc}}$ for amiloride was $0.47 \mu \mathrm{M}$ for cultured primary SCCD epithelial cells [8]. The present study has found an inhibitory effect of amiloride at $100 \mu \mathrm{M}(84 \%)$ that is similar to that found earlier (81\%) [8]. The $\mathrm{IC}_{50}$ for SCCD is similar to the $\mathrm{IC}_{50}$ value of amiloride in Reissner's membrane $(0.7 \mu \mathrm{M})$ [22] (Table 2).

\section{Cation selectivity of other channels}

CNGA1 (cyclic nucleotide gated) channels were "Present" in our gene array of rat SCCD (GEO GSE6197), but "Absent" in mouse Reissner's membrane (GEO GSE6196), another inner ear $\mathrm{Na}^{+}$-absorptive epithelium. This is an amiloride-insensitive channel (not inhibited by $100 \mu \mathrm{M}$ amiloride [23]) that has a low cation selectivity [24-27]. This channel therefore does not contribute to the $\mathrm{Na}^{+}$currents reported here.

HCN1 and HCN3 (hyperpolarization-activated cyclic nucleotide-gated) channels are "Present" in our gene array of rat SCCD. $\mathrm{HCN}$ channels conduct $\mathrm{Na}^{+}$and $\mathrm{K}^{+}$ with permeability ratios of about 1:3 [28,29]. Despite this preference for $\mathrm{K}^{+}, \mathrm{HCN}$ channels carry an inward $\mathrm{Na}^{+}$ 
current under physiological conditions [30]. There are no reports of amiloride sensitivity of $\mathrm{HCN}$ channels. ASIC1a (acid sensitive ion channels) are "Present" in our gene array of rat SCCD. $\mathrm{IC}_{50}$ value for amiloride of ASIC1a is $10 \mu \mathrm{M}$ and $\mathrm{P}_{\mathrm{Na}} / \mathrm{P}_{\mathrm{K}}$ is $6-13[18,31,32]$ (Table 2). The HCN1, HCN3 and ASIC1a channels therefore do not contribute to the $\mathrm{Na}^{+}$currents reported here.

\section{The culture of epithelial cells with permeable and impermeable support}

A previous report on primary SCCD epithelial cells that were cultured on permeable supports demonstrated the block of $\mathrm{I}_{\mathrm{sc}}$ by amiloride ( $\mathrm{IC}_{50} 470 \mathrm{nM}$ ) and benzamil (57 $\mathrm{nM}$ ) [8]. In the present study, we found that amiloride inhibited $\mathrm{Na}^{+}$current and did not inhibit $\mathrm{K}^{+}$currents (in both Ussing chamber recordings and whole cell recordings) when cells were cultured on permeable supports. These results are consistent with currents mediated by heteromeric $\mathrm{ENaC}$. On the other hand, whole-cell currents passed $\mathrm{K}^{+}$as well as $\mathrm{Na}^{+}$and were insensitive to amiloride when cells were cultured on impermeable supports. These results are consistent with currents mediated by nonselective cation channels of an unidentified molecular origin. Homomeric alpha- $\mathrm{ENaC}$ is not a likely candidate since the currents were amiloride-insensitive.

These observations are consistent with a fundamental change in ion channel expression that was dependent on the culture substrate. Similar observations were made previously on other cells. Alveolar type II (ATII) cells also express highly-selective $\mathrm{Na}^{+}$channels (HSC) when cultured on permeable supports but nonselective cation channels when cultured on impermeable supports [33]. $\mathrm{H} 441$ lung adenocarcinoma cells also alter the $\mathrm{Na}^{+}$selectivity of their transport under the two conditions [34]. These results are a strong cautionary note for the culture of epithelial cells. Presumably there is a basolateral accumulation of a waste product that cannot diffuse adequately into the bath and triggers a change in channel expression.

\section{Conclusions}

The results of this study support the conclusion that the amiloride-sensitive current in SCCD epithelial cells is highly selective for $\mathrm{Na}^{+}$and does not support the transport of $\mathrm{K}^{+}$. When this is combined with the results of previous studies on the amiloride-sensitive transepithelial current, it suggests that SCCD contributes to maintaining the low $\mathrm{Na}^{+}$concentration in normal endolymph but is not involved in $\mathrm{K}^{+}$homeostasis through this pathway.

\section{Methods}

Tissue preparation and electrophysiological recordings Primary culture of SCCD epithelia

SCCD were dissected from neonatal Wistar rats (3-5 days), as described previously [8,12] and followed protocols in compliance with internationally recognized guidelines with approval by the Kansas State University Institutional Animal Care and Use Committee. Epithelial cells from SCCD, exclusive of common crus, were dispersed and seeded on Transwell permeable supports (6.5 mm diameter, Costar 3470, Corning, NY) or on glass cover slips $(3 \mathrm{~mm} \times 5 \mathrm{~mm})$ and cultured with DMEM/F-12 medium (Invitrogen 12500-062, Carlsbad, CA) supplemented with $5 \%$ fetal bovine serum, penicillin $(100 \mathrm{U} / \mathrm{ml})$ and streptomycin $(100 \mu \mathrm{g} / \mathrm{ml})$ (SigmaAldrich \#P-7539). The cells were used within 6 to 12 days after seeding and confluence of the primary cultures on permeable supports (4-6 days after seeding) was verified by measurement of transepithelial resistance. Cultures were treated with dexamethasone (100 $\mathrm{nM}$ ) for $24 \mathrm{~h}$ before recordings of $\mathrm{I}_{\mathrm{sc}}$ or whole cell currents.

\section{Ussing chamber recordings of the SCCD}

$\mathrm{I}_{\mathrm{sc}}$ was measured as described previously [8] from confluent monolayers of SCCD in an Ussing chamber (AH 660001, Harvard Apparatus, Holliston, MA) modified to accept the Transwells, maintained at $37^{\circ} \mathrm{C}$ and connected to a voltage/current clamp amplifier (model VCC MC8, Physiologic Instruments, San Diego, CA) via $\mathrm{Ag} / \mathrm{AgCl}$ electrodes and HEPES-buffered bath solution bridges with $3 \%$ agar. $\mathrm{I}_{\mathrm{sc}}$ was directly measured under voltage clamp (short circuit conditions) and both apical and basolateral side solutions were stirred by bubbling air.

\section{Whole cell recordings of the SCCD}

Cover slips or filter inserts with an SCCD epithelial monolayer were mounted in a chamber $(150 \mu \mathrm{l})$ on an inverted microscope and perfused with bath solution at a rate of $150 \mu \mathrm{l} / \mathrm{s}$. The patch pipettes were pulled in two steps from borosilicate glass capillaries (WPI, 1B150F-4) using a vertical puller (PP-83, Narishige) and had a resistance of 8-12 M $\Omega$. After achieving a high-resistance seal (> $1.5 \mathrm{G} \Omega$ ), the whole cell patch configuration was achieved by rupturing the cell membrane with suction; we were only successful about 1 time out of $\sim 80-100$ trials due to the thinness of the cells and the rigidity of the support. Electrodes were connected to an Axopatch 200A amplifier (Axon Instruments/Molecular Devices Corp., Sunnyvale, CA) at a low-pass filter bandwidth of $1 \mathrm{kHz}$ (four-pole Bessel). Recordings were made at $36-37^{\circ} \mathrm{C}$. Membrane currents were recorded with a Digidata 1322A (Axon Instruments) interface and pCLAMP 9 software (Axon Instruments) at a sampling rate of $10 \mathrm{kHz}$. The same software was used for the analyses. Stability of the patch was ascertained by monitoring the cell capacitance $\left(\mathrm{C}_{\text {cell }}\right)$ and resistance $\left(\mathrm{R}_{\text {cell }}\right)$ at the beginning and the end of recordings; $C_{\text {cell }}$ changed less than 1 $\mathrm{pF}$ during experiments. The initial $\mathrm{C}_{\text {cell }}$ for cells on permeable supports was $20.9 \pm 3.6 \mathrm{pF}(\mathrm{n}=14$ and on impermeable supports was $15.5 \pm 2.0 \mathrm{pF}(\mathrm{n}=13)$. The 
holding potential was $0 \mathrm{mV}$ and the voltage command protocol consisted of 10 voltage steps with $20 \mathrm{mV}$ spacing from $-120 \mathrm{mV}$ to $+60 \mathrm{mV}, 200 \mathrm{~ms}$ per step. Data are presented with command voltages corrected for liquid junction potentials $\left(16.1 \mathrm{mV}\right.$ in $\mathrm{Na}^{+}$-rich bath and 20.4 $\mathrm{mV}$ in $\mathrm{K}^{+}$-rich bath, calculated with Axon Instruments implementation of the JPCalcW program by Peter $\mathrm{H}$. Barry and additional ion mobility values, http://web.med. unsw.edu.au/phbsoft/mobility_listings.htm). Currents were normalized by cell capacitance as a measure of cell membrane surface area.

\section{Solutions and chemicals}

All reagents were from Sigma-Aldrich, unless otherwise stated. Amiloride (no. A-7410) was predissolved in dimethylsulfoxide (DMSO), which was used at a final concentration of $0.1 \%$ DMSO. Amiloride was added to the apical side bath at a final concentration of $100 \mu \mathrm{M}$. Dexamethasone-cyclodextrin complex (\#D-2915), was pre-dissolved in water.

\section{Whole cell recordings of the $S C C D$}

The impermeant anions gluconate ${ }^{-}$and methanesulfonate ${ }^{-}$were used to exclude any possible contributions from anions to the measured currents. The bath solutions were 1$) \mathrm{Na}^{+}$-rich- $(\mathrm{mM}) 150 \mathrm{Na}$-gluconate, 0.25 MgSO4, 1 Ca-gluconate, 10 HEPES and 5 glucose, $\mathrm{pH}$ 7.4 adjusted with $\mathrm{NaOH}, 2) \mathrm{K}^{+}$-rich- (mM) $150 \mathrm{~K}$-gluconate, $0.25 \mathrm{MgSO} 4,1 \mathrm{Ca}$-gluconate, $10 \mathrm{HEPES}$ and 5 glucose, $\mathrm{pH} 7.4$ adjusted with $\mathrm{KOH}$. The osmolarity of both bath solutions was 315-320 mOsm.

The pipette electrodes were filled with the following two solutions in each electrode; tip solutions dialyzed the cells and the back fill solutions made contact with the $\mathrm{Ag} / \mathrm{AgCl}$ electrode. For use with the $\mathrm{Na}^{+}$-rich bath, $\sim 10$ $\mathrm{mm}$ of the pipette tip was filled with (mM): 135 NMDGmethanesulfonate, $15 \mathrm{Na}$-gluconate, $5 \mathrm{Mg}$-ATP, 1 EGTA and 10 HEPES, pH 7.4 and the backfilling solution was identical except that $15 \mathrm{Na}$-gluconate was replaced by 15 $\mathrm{NaCl}$ and the water-soluble dye fast green added for visualization. For use with the $\mathrm{K}^{+}$-rich bath, the pipette tip solution contained (mM): 135 NMDG-methanesulfonate, $15 \mathrm{~K}$-gluconate, $5 \mathrm{Mg}$-ATP, 1 EGTA and $10 \mathrm{HEPES}$ and the backfilling solution was identical except that 15 $\mathrm{K}$-gluconate was replaced by $15 \mathrm{KCl}$.

\section{Ussing chamber recordings of the SCCD}

The composition of the basolateral side solution was (mM) $145 \mathrm{NaCl}, 5 \mathrm{KCl}, 1.2 \mathrm{MgCl} 2,1.2 \mathrm{CaCl} 2,10$ HEPES and 5 Glucose, pH 7.4 adjusted with $\mathrm{NaOH}$. The composition of the apical side solution was (mM) $150 \mathrm{NaCl}, 0.25 \mathrm{MgCl} 2,0.25 \mathrm{CaCl} 2,10$ HEPES, pH 7.4 adjusted with $\mathrm{NaOH}$; in the substitution experiments, $150 \mathrm{mM} \mathrm{NaCl}$ was replaced by $150 \mathrm{mM} \mathrm{KCl}, \mathrm{pH} 7.4$ adjusted with $\mathrm{KOH}$.

\section{Gene array analysis}

Total RNA was extracted from control $(\mathrm{n}=4)$ and dexamethasone-treated $(\mathrm{n}=4)$ samples of SCCD primary cultures using RNeasy Micro Kit. The quality and quantity were determined as described previously [12]. Affymetrix microarrays were used to examine the expression of the genes investigated here by electrophysiology. Our methodology conforms to the MIAME (Minimum Information about a Microarray Experiment) guidelines and details are deposited with the data in [GEO: GSE6197] [6].

\section{Statistical analysis}

Data were expressed as the mean \pm S.E.M. $(n=$ number of whole cell patches or inserts for $\mathrm{I}_{\mathrm{sc}}$ ).

The significance of increases and decreases in current were determined by Student's paired or unpaired t-test. Differences were considered statistically significant at a level of $\mathrm{P}<0.05$ (Microsoft Excel).

\section{Acknowledgements}

This work was supported by NIH grants R01-DC00212 and P20-RR017686 to DCM. We thank Dr. Philine Wangemann for helpful discussions and Joel D. Sanneman for technical assistance. The original suggestion to investigate cation selectivity in these cells was made by Dr. James Stockand.

\section{Author details}

'Cellular Biophysics Laboratory, Department of Anatomy \& Physiology, Kansas State University, Manhattan, KS 66506, USA. ²Department of Otolaryngology-Head and Neck Surgery, Tohoku University Graduate School of Medicine, Sendai, Japan 980-8574.

\section{Authors' contributions}

MY extensively analyzed data and contributed to writing the manuscript. TW carried out the patch clamp recordings. SRP carried out the Ussing chamber recordings; his new address is 112 Greene Hall, Department of Anatomy, Physiology and Pharmacology, College of Veterinary Medicine, Auburn University, Auburn, AL 36849. DGH assisted the study, including microdissection of tissues and Ussing chamber recordings. DCM conceived of the study, participated in its design and direction and contributed to writing the manuscript. All authors read and approved the final manuscript.

\section{Competing interests}

The authors declare that they have no competing interests.

Received: 23 August 2011 Accepted: 13 September 2011 Published: 13 September 2011

\section{References}

1. Marcus DC, Wangemann P: Cochlear and Vestibular Function and Dysfunction. In Physiology and Pathology of Chloride Transporters and Channels in the Nervous System-From molecules to diseases. Edited by: Alvarez-Leefmans FJ, Delpire E. New York: Elsevier; 2009:425-437.

2. Marcus DC, Wangemann P: Inner ear fluid homeostasis. In The Oxford Handbook of Auditory Science: The Ear. Edited by: Fuchs PA. Oxford: Oxford University Press; 2010:213-230.

3. Shi $X$, Gillespie PG, Nuttall AL: Na+ influx triggers bleb formation on inner hair cells. Am J Physiol Cell Physiol 2005, 288:C1332-C1341.

4. Kim SH, Marcus DC: Regulation of sodium transport in the inner ear. Hear Res 2011.

5. Yamazaki M, Kim KX, Marcus DC: Sodium selectivity of Reissner's membrane epithelial cells. BMC Physiol 2011, 11:4 
6. Pondugula SR, Raveendran NN, Marcus DC: Ion transport regulation by $\mathrm{P} 2 \mathrm{Y}$ receptors, protein kinase $\mathrm{C}$ and phosphatidylinositol 3-kinase within the semicircular canal duct epithelium. BMC Res Notes 2010, 3:100.

7. Marcus DC, Raveendran NN, Pondugula SR: Rat Semi-Circular Canal Duct Gene Expression Studies. 2011 [http://www.ncbi.nlm.nih.gov/geo/query/ acc.cgi?acc=GSE6197].

8. Pondugula SR, Sanneman JD, Wangemann P, Milhaud PG, Marcus DC: Glucocorticoids stimulate cation absorption by semicircular canal duct epithelium via epithelial sodium channel. Am J Physiol Renal Physiol 2004, 286:F1127-F1135.

9. Sellick PM, Johnstone JR, Johnstone BM: The electrophysiology of the utricle. Pflugers Arch 1972, 336:21-27.

10. Scherer EQ, Yang J, Canis M, Reimann K, Ivanov K, Diehl CD, Backx PH, Wier WG, Strieth S, Wangemann P, Voigtlaender-Bolz J, Lidington D, Bolz SS: Tumor necrosis factor-alpha enhances microvascular tone and reduces blood flow in the cochlea via enhanced sphingosine-1-phosphate signaling. Stroke 2010, 41:2618-2624.

11. Dagenais A, Frechette R, Yamagata Y, Yamagata T, Carmel JF, Clermont ME, Brochiero E, Masse C, Berthiaume Y: Downregulation of ENaC activity and expression by TNF-alpha in alveolar epithelial cells. Am J Physiol Lung Cell Mol Physiol 2004, 286:L301-L311.

12. Pondugula SR, Raveendran NN, Ergonul Z, Deng Y, Chen J, Sanneman JD, Palmer LG, Marcus DC: Glucocorticoid Regulation of Genes in the Amiloride-Sensitive Sodium Transport Pathway by Semicircular Canal Duct Epithelium of Neonatal Rat. Physiol Genomics 2006, 24:114-123.

13. Dagenais A, Frechette R, Clermont ME, Masse C, Prive A, Brochiero E, Berthiaume Y: Dexamethasone inhibits the action of TNF on ENaC expression and activity. Am J Physiol Lung Cell Mol Physiol 2006, 291: L1220-L1231.

14. Matalon S, Lazrak A, Jain L, Eaton DC: Invited review: biophysical properties of sodium channels in lung alveolar epithelial cells. J Appl Physiol 2002, 93:1852-1859.

15. Kizer N, Guo XL, Hruska K: Reconstitution of stretch-activated cation channels by expression of the alpha-subunit of the epithelial sodium channel cloned from osteoblasts. Proc Natl Acad Sci USA 1997, 94:1013-1018.

16. Canessa CM, Schild L, Buell G, Thorens B, Gautschi I, Horisberger JD, Rossier BC: Amiloride-sensitive epithelial $\mathrm{Na}+$ channel is made of three homologous subunits. Nature 1994, 367:463-467.

17. Kellenberger S, Hoffmann-Pochon N, Gautschi I, Schneeberger E, Schild L: On the molecular basis of ion permeation in the epithelial $\mathrm{Na}+$ channel. J Gen Physiol 1999, 114:13-30.

18. Kellenberger S, Schild L: Epithelial sodium channel/degenerin family of ion channels: a variety of functions for a shared structure. Physiol Rev 2002, 82:735-767.

19. McNicholas CM, Canessa CM: Diversity of channels generated by different combinations of epithelial sodium channel subunits. J Gen Physiol 1997, 109:681-692

20. Alvarez de la Rosa D, Canessa CM, Fyfe GK, Zhang P: Structure and regulation of amiloride-sensitive sodium channels. Annu Rev Physiol 2000, 62:573-594.

21. Ismailov II, Kieber-Emmons T, Lin C, Berdiev BK, Shlyonsky VG, Patton HK, Fuller CM, Worrell R, Zuckerman JB, Sun W, Eaton DC, Benos DJ, Kleyman TR: Identification of an amiloride binding domain within the alpha-subunit of the epithelial $\mathrm{Na}+$ channel. J Biol Chem 1997, 272:21075-21083.

22. Kim SH, Kim KX, Raveendran NN, Wu T, Pondugula SR, Marcus DC Regulation of ENaC-mediated sodium transport by glucocorticoids in Reissner's membrane epithelium. Am J Physiol Cell Physiol 2009, 296: C544-C557.

23. Wilkinson WJ, Benjamin AR, De P, Orogo-Wenn MC, Yamazaki Y, Staub O, Morita T, Adriaensen D, Riccardi D, Walters DV, Kemp PJ: Alveolar epithelial CNGA1 channels mediate cGMP-stimulated, amiloride-insensitive, lung liquid absorption. Pflugers Arch 2011.

24. Mazzolini M, Marchesi A, Giorgetti A, Torre V: Gating in CNGA1 channels. Pflugers Arch 2010, 459:547-555.

25. Vandorpe DH, Ciampolillo F, Green RB, Stanton BA: Cyclic nucleotide-gated cation channels mediate sodium absorption by IMCD (mIMCD-K2) cells. Am J Physiol Cell Physiol 1997, 272:C901-C910.

26. Kaupp UB, Seifert R: Cyclic nucleotide-gated ion channels. Physiol Rev 2002, 82:769-824.
27. Menini A: Currents carried by monovalent cations through cyclic GMPactivated channels in excised patches from salamander rods. J Physiol 1990, 424:167-185

28. Stieber J, Stockl G, Herrmann S, Hassfurth B, Hofmann F: Functional expression of the human HCN3 channel. J Biol Chem 2005, 280:34635-34643.

29. Aponte $Y$, Lien CC, Reisinger E, Jonas P: Hyperpolarization-activated cation channels in fast-spiking interneurons of rat hippocampus. J Physio/ 2006, 574:229-243.

30. Wahl-Schott C, Biel M: HCN channels: structure, cellular regulation and physiological function. Cell Mol Life Sci 2009, 66:470-494.

31. Kapoor N, Bartoszewski R, Qadri YJ, Bebok Z, Bubien JK, Fuller CM, Benos DJ: Knockdown of ASIC1 and epithelial sodium channel subunits inhibits glioblastoma whole cell current and cell migration. $J$ Biol Chem 2009, 284:24526-24541

32. Waldmann R, Champigny G, Bassilana F, Heurteaux C, Lazdunski M: A proton-gated cation channel involved in acid-sensing. Nature 1997, 386:173-177.

33. Jain L, Chen XJ, Ramosevac S, Brown LA, Eaton DC: Expression of highly selective sodium channels in alveolar type II cells is determined by culture conditions. Am J Physiol Lung Cell Mol Physiol 2001, 280:L646-L658.

34. Shlyonsky V, Goolaerts A, Van Beneden R, Sariban-Sohraby S: Differentiation of epithelial $\mathrm{Na}+$ channel function. An in vitro model J Biol Chem 2005, 280:24181-24187.

35. Lyashchenko AK, Tibbs GR: lon binding in the open HCN pacemaker channel pore: fast mechanisms to shape "slow" channels. J Gen Physiol 2008, 131:227-243.

36. Mergler S, Garreis F, Sahlmuller M, Reinach PS, Paulsen F, Pleyer U: Thermosensitive transient receptor potential channels in human corneal epithelial cells. J Cell Physiol 2011, 226:1828-1842.

37. Kichko TI, Reeh PW: TRPV1 controls acid- and heat-induced calcitonin gene-related peptide release and sensitization by bradykinin in the isolated mouse trachea. Eur J Neurosci 2009, 29:1896-1904.

doi:10.1186/1756-0500-4-355

Cite this article as: Yamazaki et al: Sodium selectivity of semicircular canal duct epithelial cells. BMC Research Notes 2011 4:355.

\section{Submit your next manuscript to BioMed Central and take full advantage of:}

- Convenient online submission

- Thorough peer review

- No space constraints or color figure charges

- Immediate publication on acceptance

- Inclusion in PubMed, CAS, Scopus and Google Scholar

- Research which is freely available for redistribution 